\title{
Differences in nasal cellular infiltrates between allergic children and age-matched controls
}

\author{
J.G. Vinke, A. KleinJan, L.W.F.M. Severijnen, L.J. Hoeve, W.J. Fokkens
}

\begin{abstract}
Differences in nasal cellular infiltrates between allergic children and age-matched controls. J.G. Vinke, A. KleinJan, L.W.F.M. Severijnen, L.J. Hoeve, W.J. Fokkens. (C)ERS Journals Ltd 1999.

ABSTRACT: Little is known about the cellular infiltrates in the nasal mucosa of children. This study was set up to compare the nasal cellular infiltrates in biopsy specimens from allergic children and controls.

Atopic children were distinguished from controls on the basis of symptoms of allergic rhinitis and/or asthma, total serum immunoglobulin (Ig)E, family history and specific serum IgE to food and aeroallergens. Fifteen allergic patients (median age 4.3 yrs) and 15 age-matched nonallergic control subjects were evaluated. The number of cells positive for CD1a, CD4, CD8, CD19, CD68, chymase, tryptase, IgE and major basic protein was determined in the mucosa of the inferior turbinate.

A significantly higher number of IgE-positive cells and mast cells was found in the epithelia of the allergic group. In the lamina propria, higher numbers of IgE-positive cells and eosinophils were found. Langerhans' cells positive for IgE were only seen in allergic children with specific serum IgE against aeroallergens. These children also had a higher number of IgE-positive mast cells compared to controls and atopic children without specific serum IgE.

These results show that the nasal cellular infiltrates of allergic children differ from nonallergic control subjects. Prior to the detection of specific serum immunoglobulin $E$, cellular changes can be found in the nasal mucosa of atopic children. Eur Respir J 1999; 13: 797-803.
\end{abstract}

Dept of Otorhinolaryngology, Erasmus University Medical Centre Rotterdam, Rotterdam, The Netherlands.

Correspondence: J.G.Vinke

Dept of Otorhinolaryngology

University Hospital Dijkzigt

Erasmus University Medical Centre Rotterdam

Dr. Molewaterplein 40

3015 GD Rotterdam

The Netherlands

Fax: 31104367146

Keywords: Allergic rhinitis

biopsy

children

eosinophils

immunoglobulin E

nasal mucosa

Received: July 81998

Accepted after revision November 191998

This study was supported by research grant 94-51 from the Dutch Asthma Foundation.
Allergic rhinitis is the result of an adverse immune response to inert environmental antigens. From birth onward the nasal mucosa is continuously exposed to potential allergens. In a certain percentage of "genetically predisposed" children, this exposure leads to sensitization of the immune system. Following this process, allergen-specific immunoglobulin $(\mathrm{Ig}) \mathrm{E}$ is produced. This in turn gives rise to the typical symptoms associated with allergic rhinitis (e.g. rhinorrhoea, nasal congestion, itching and sneezing).

In the last three decades, an increase in the prevalence of allergic rhinitis and related atopic diseases has been reported [1]. This has been demonstrated in various European countries in both children and young adults $[2,3]$. Recent years have seen the accumulation of information on cellular changes in the nasal mucosa in fully developed allergic disease [4-8]. Such studies were performed on nasal biopsy specimens from adults and therefore only shed light on the cellular changes in full-blown allergic disease. Although allergic disease usually starts at an early age, no data has been produced on cellular infiltrates in the nasal mucosa of atopic children.

The present study reports on the hypothesis that cellular infiltrates in the nasal mucosa of atopic children differ from those of nonallergic children. Some studies have been performed to demonstrate this possible difference. However these studies used nasal lavage or scrapings to obtain cells from the mucosa [9-12]. Without exception, these studies all report differences in eosinophil and/or mast cell num- bers between allergic children and controls. However, LiM et al. [13] have pointed out that nasal secretions and nasal mucosa represent two different compartments.

A further shortcoming of studies using nasal lavage or scrapings is the fact that only a limited number of cell types can be studied. To understand the dynamics of the development of allergic disease it is of paramount importance to study all cell types in the different compartments of the nasal mucosa. The present study was performed to obtain greater insight into cellular changes during the development of allergic disease. Connecting these cellular changes with the presence of (specific) serum IgE may prove to be of relevance in the understanding of allergic rhinitis in children.

\section{Methods}

\section{Patients and controls}

This study was performed with the approval of the Medical Ethics Committee of Erasmus University Medical Centre Rotterdam. In the period from May to December 1996 children undergoing adeno(tonsillec)tomy were asked to participate in the study. The parents or guardians of 54 children gave their written informed consent. The total group consisted of 35 males and 19 females, with a median age of 4.4 yrs (range 1.2-12.7). 


\section{Study design}

The medical history of all children was taken by a physician on the basis of an extensive questionnaire. Data were collected on symptoms and signs of the children's disease(s), medication, rhinitis, asthma, eczema and family history with respect to allergy. During surgery, a blood sample was taken to measure total and specific IgE. This was carried out using Phadiatop radioimmunoassay (RIA) and radioallergosorbent test (RAST) (Pharmacia CAP System, Uppsala, Sweden). The allergens most relevant to infants and children, such as food allergens (milk protein, egg white, peanut and soya) and aeroallergens (AA) (house dust mite, grass pollen and cat and dog epithelium) were tested. Prior to adeno(tonsillec)tomy, a biopsy was taken from the right inferior turbinate.

Children were included in the allergic group if they fulfilled one of the following set of inclusion criteria: 1) signs and symptoms of rhinitis and/or asthma and specific $\operatorname{IgE}$ to AA, 2) rhinitis and/or asthma, a high total $\operatorname{IgE}$ for their age $\left(>10 \mathrm{IU} \cdot \mathrm{yr}\right.$ of age $\left.\mathrm{a}^{-1}\right)$ and a positive family history (defined as having at least one first degree family member with a proven allergy to AA), or 3) rhinitis and/or asthma, a high total $\operatorname{IgE}$ for their age and specific $\operatorname{IgE}$ to food allergens.

Children were included in the control group if they had no symptoms of allergic disease together with a low total IgE for their age $\left(<10 \mathrm{IU} \cdot \mathrm{yr}\right.$ of age $\left.\mathrm{g}^{-1}\right)$, no specific serum IgE for food and AA and a negative family history for atopic disease. Children were excluded from both groups when parents did not give an informed consent, when the child had purulent rhinitis at the time of surgery and when systemic or topical corticosteroids had been used in the 2 months prior to surgery.

Of the 54 children studied, 15 (28\%) children fulfilled the inclusion criteria for allergy. Fifteen age-matched controls were selected. The allergic group consisted of 12 males and three females, with a median age of $4.3 \mathrm{yrs}$ (range 2.06.5 ) and a median total serum $\mathrm{IgE}$ of $267 \mathrm{IE} \cdot \mathrm{mL}^{-1}$ (range 76-902) (table 1). The control group consisted of nine

Table 1. - Details of inclusion criteria for allergic children

\begin{tabular}{lccccc}
\hline $\begin{array}{l}\text { Patient } \\
\text { No. }\end{array}$ & Sex & $\begin{array}{c}\text { Age } \\
\text { yrs }\end{array}$ & $\begin{array}{c}\text { Total } \\
\text { serum IgE } \\
\text { IU·mL }\end{array}$ & $\begin{array}{c}\text { Specific IgE } \\
\text { against* }\end{array}$ & $\begin{array}{c}\text { Positive } \\
\text { family } \\
\text { history }\end{array}$ \\
\hline 1 & M & 2 & 356 & Food allergens & Y \\
2 & M & 2.4 & 76 & None & Y \\
3 & M & 2.4 & 232 & Aero+food allergens & N \\
4 & M & 2.6 & 76 & Food allergens & N \\
5 & M & 3.1 & 156 & Food allergens & Y \\
6 & M & 3.3 & 271 & None & Y \\
7 & F & 3.8 & 86 & Aeroallergens & Y \\
8 & M & 4.2 & 902 & Aero+food allergens & N \\
9 & M & 4.2 & 123 & None & Y \\
10 & M & 5.3 & 78 & Aeroallergens & N \\
11 & F & 5.6 & 163 & None & Y \\
12 & M & 5.8 & 568 & Aero+food allergens & Y \\
13 & M & 5.9 & NA & Aero+food allergens & Y \\
14 & M & 6.3 & 680 & Aeroallergens & Y \\
15 & F & 6.5 & 495 & None & Y \\
\hline
\end{tabular}

*: Determined by radioimmunosorbent assay; ${ }^{+}$: at least one first-degree family-member with proven allergy. IgE: immunoglobulin E; M: male; F: female; NA: not available; Y: yes; N: no. males and six females with a median age of 4.2 yrs (range 2.6-5.8) and a median total serum IgE of $17 \mathrm{IU} \cdot \mathrm{mL}^{-1}$ (range $<2-50$ ).

\section{Tissue collection}

During general anaesthesia, a biopsy specimen of the right inferior turbinate was removed using Gerritsma forceps [14]. No local anaesthetic or topical decongestant was used prior to taking the biopsy. The specimens were embedded in Tissue-tek II OCT compound (Miles, Inc. Diagnostics Div., Tarrytown, NY, USA) in a gelatin capsule, snap-frozen in liquid nitrogen and stored at $-196^{\circ} \mathrm{C}$. From each biopsy specimen, $6-\mu \mathrm{m}$-thick serial sections were cut on a Reichert-Jung 2800 Frigocut cryostat (Cambridge Instruments, Nussloch, Germany) and transferred to a poly-L-lysine-coated microscope slide. For each patient, two sequential sections were placed on the slide. After transfer, tissue sections were air-dried and stored at $-80^{\circ} \mathrm{C}$ until immunohistochemical staining was performed.

\section{Single staining}

Tissue sections were stained by means of a very sensitive alkaline phosphatase (AP) method using the semiautomatic sequenza system (Shanden, Pittsburg, PA, USA). Prior to staining, sections were fixed in acetone for $10 \mathrm{~min}$. The sections were then rinsed in phosphate-buffered saline (PBS, pH 7.4) for $5 \mathrm{~min}$, incubated in $10 \%$ normal goat serum for $10 \mathrm{~min}$ and incubated with a mouse monoclonal antibody for $1 \mathrm{~h}$ at $20^{\circ} \mathrm{C}$. The following antibodies were used: Okt 6 (Dept Immunology, Erasmus University, the Netherlands) directed against Langerhans' cells CD1a; Leu 3 and Leu 2a (Becton Dickinson, Dorset, UK) directed against T-cells CD4 and CD8 respectively; Mon/1 (CLB, Amsterdam, the Netherlands) directed against granulocyte/macrophage CD14; IOB4a (Immunotech, Marseille, France) directed against B-cell CD19; KI-M6 (Behring, Marburg, Germany) directed against macrophage CD68; BMK 13 (Sambio, Uden, the Netherlands) directed against eosinophil major basic protein (MBP); B7 and G3 (Chemicon, Temecula, CA, USA) directed against mast cell chymase and tryptase respectively and $\alpha-\operatorname{IgE}$ (CLB) directed against IgE. After incubation with the primary antibody the sections were rinsed in PBS for $5 \mathrm{~min}$ and incubated for $30 \mathrm{~min}$ with biotinylated goat anti-mouse Ig serum, diluted 1:50 in PBS supplemented with 10\% normal human serum (to saturate Fc receptors and to reduce background staining) (BioGenex, San Ramon, CA, USA), rinsed in PBS for $5 \mathrm{~min}$, followed by incubation with streptavidin-AP (BioGenex) and diluted 1:50 with 10\% normal human serum. Subsequently, the sections were rinsed in PBS followed by tris-hydroxymethyl-amino methane (Tris) buffer, $\mathrm{pH} 8.5$, and incubated with new fuchsin substrate in the dark at room temperature. After staining the sections were rinsed with distilled water, counterstained with Gill's haematoxylin, triple strength, washed in running tap water and mounted in glycerolgelatin. Control staining was performed by the substitution of primary monoclonal antibodies by PBS. 


\section{Double staining}

Sections were fixed in acetone for $10 \mathrm{~min}$ and rinsed in PBS (pH 7.4). Endogenous peroxidase was blocked with $1 \%$ sodium azide and $0.01 \%$ hydrogen peroxide in PBS for $30 \mathrm{~min}$. Following this, the sections were rinsed in PBS for $10 \mathrm{~min}$ and incubated with $10 \%$ normal goat serum. Subsequently, sections were incubated with mouse antiCD1a or mouse anti-tryptase and anti-chymase in equal amounts (for specification see single staining section). After $1 \mathrm{~h}$ sections were rinsed with PBS for $5 \mathrm{~min}$, incubated with goat anti-mouse AP (Immunotech) for 30 min and rinsed once more with PBS for 5 min. After that, sections were incubated with mouse anti-AP conjugated to AP (Dako, Copenhagen, Denmark) and rinsed with PBS for $5 \mathrm{~min}$. This first step in the double staining procedure was followed by a second step directed at IgE. Sections were incubated with rabbit anti-IgE polyclonal antibodies (Dako) for $1 \mathrm{~h}$. They were rinsed with PBS for $5 \mathrm{~min}$, incubated with peroxidase-conjugated porcine anti-rabbit antibody (Dako) and 10\% normal human serum for 30 min. Finally, samples were rinsed with PBS and Tris buffer (0.1 M, pH 8.5) for $5 \mathrm{~min}$. This was followed by incubation for $30 \mathrm{~min}$ in fast blue substrate. Samples were rinsed with sodium acetate $(0.1 \mathrm{M}, \mathrm{pH} 4.6)$ for $5 \mathrm{~min}$ and incubated with aminoethylcarbazole substrate for $30 \mathrm{~min}$. Control staining was performed by substitution of primary monoclonal antibodies by an irrelevant antibody and PBS.

\section{Light microscopic evaluation}

Cells binding the monoclonal antibodies had bright redsurface membranes, red stained cytoplasm or both, depending on the antibody and/or cell type evaluated. The total number of positive cells was determined separately by two independent researchers. The number of positive cells in the epithelium and lamina propria was scored.

T-cells, CD14+, CD19+ and CD68+ and all doublestaining experiments were counted at a $400 \times$ magnification. All other cell types were counted at a $200 \times$ magnification. Cells were said to be double-stained when both colour signals (red and blue) were seen around one cell nucleus, or when both signals had mingled to form a purple colour.

For each patient, two sections were evaluated. In each section the total surface area of epithelium and lamina propria was measured using the Kontron Image Analysis System Videoplan 2.1 (Zeiss, Weesp, the Netherlands). For all patients, an average of $0.4 \mathrm{~mm}^{2}$ and $2.2 \mathrm{~mm}^{2}$ was found for the epithelium and lamina propria, respectively. Subsequently the total cell number. $\mathrm{mm}^{-2}$ was calculated.

\section{Statistical analysis}

As sections were counted blindly by two independent researchers, interobserver reliability was determined. This was carried out by calculating the Spearman rank correlation. For each cell type a strong correlation was found $\left(\mathrm{r}_{\mathrm{s}}\right.$ $>0.85, \mathrm{p} \leq 0.05)$.

The statistical analysis of cell numbers was performed using SPSS (version 6.1 for Windows; SPSS, Chicago, IL, USA). As the cells $\cdot \mathrm{mm}^{-2}$ did not show a normal distribution, the nonparametric Mann-Whitney U-test was used. As multicomparisons were made in this study, the p-value had to be $\leq 0.01$ to show a statistically significant difference between the groups.

Correlation and statistical significance between total serum $\operatorname{IgE}$ and the number of positive cells for each cell type were determined using the Spearman rank test $\left(r_{s}>0.8\right.$ and $\mathrm{p} \leq 0.05)$.

\section{Results}

\section{Biopsy procedure}

The first three subjects participating in this study all suffered from slight epistaxis from the biopsy site after surgery. These children were treated with a topical decongestant (xylometazoline $0.05 \%$ ) after which the epistaxis stopped. To prevent postoperative epistaxis in future patients, it was decided to install nasal packing $(1 \times 15 \mathrm{~cm})$ soaked in xylometazoline $0.05 \%$ immediately after biopsy. The nasal packing was removed $30 \mathrm{~min}$ after surgery. This procedure substantially reduced postoperative epistaxis. Only three of the remaining 51 patients had postoperative epistaxis from the biopsy site after this change in procedure. One child had to be readmitted for observation because of epistaxis.

\section{General description}

All but one (excluded from the study) of the 54 biopsy specimens showed virtually intact epithelium and lamina propria. The biopsy specimens predominantly showed columnar epithelium containing goblet cells. In all cases the epithelium could be clearly distinguished from the lamina propria. The lamina propria showed a general division into two layers. A cell-rich subepithelial zone could be detected separating the epithelium from a lower layer containing the mucous glands. Both of these layers could be assessed in nearly all biopsy specimens.

\section{Distribution of total serum $\operatorname{IgE}$ in the study groups}

Levels of total serum $\operatorname{IgE}$ in allergic children were compared to those found in the nonallergic children. The median level of total serum IgE for the control group was $10 \mathrm{IU} \cdot \mathrm{mL}^{-1}$ (range $0-50$ ), whereas the median level for the allergic group was $161 \mathrm{IU} \cdot \mathrm{mL}^{-1}$ (range 78-902). This difference was statistically significant $(\mathrm{p}<0.0001)$. The allergic group consisted of two subgroups based on the presence of specific IgE against AA. The first group consisted of six children with specific serum $\operatorname{IgE}$ against $\mathrm{AA}$, whereas the second subgroup consisted of eight allergic children without specific IgE against AA. When the total serum IgE levels were compared between these two subgroups no significant difference was found, median total serum IgE $196 \mathrm{IU} \cdot \mathrm{mL}^{-1}$ (range 78-902) for the AAspecific IgE group versus $159 \mathrm{IU} \cdot \mathrm{mL}^{-1}$ (range 76-495) for the group without specific $\operatorname{IgE}$ to $\mathrm{AA}(\mathrm{p}=0.51)$.

\section{Single staining}

CDla+ cells. These cells were mainly seen in the epithelium (Langerhans' cells) in close proximity to the basal membrane and in the subepithelial space of the lamina propria. A typical dendritic appearance was seen 
Table 2. - Numbers of positive cells of cell types found in the nasal mucosa not showing significant differences between groups of allergic children and age-matched nonallergic control subjects

\begin{tabular}{|c|c|c|c|c|c|c|}
\hline \multirow{2}{*}{$\begin{array}{l}\text { Antibody } \\
\text { against }\end{array}$} & \multicolumn{2}{|c|}{ Controls } & \multicolumn{2}{|c|}{ Allergic children } & \multicolumn{2}{|c|}{$\mathrm{p}$-values } \\
\hline & Epithelium & $\begin{array}{l}\text { Lamina } \\
\text { propria }\end{array}$ & Epithelium & $\begin{array}{l}\text { Lamina } \\
\text { propria }\end{array}$ & Epithelium & $\begin{array}{c}\text { Lamina } \\
\text { propria }\end{array}$ \\
\hline CD1a & $293(32-683)$ & $25(0-90)$ & $321(83-557)$ & $45(12-200)$ & 0.8 & 0.4 \\
\hline CD4 & $1000(630-3330)$ & $730(12-1571)$ & $1594(603-3300)$ & $1044(266-2751)$ & 0.1 & 0.3 \\
\hline CD8 & $856(89-1724)$ & $441(121-1162)$ & $571(196-2706)$ & $380(121-632)$ & 0.8 & 0.4 \\
\hline CD14 & $921(28-1804)$ & $682(97-1912)$ & $1672(488-3333)$ & $1065(391-2586)$ & 0.1 & 0.02 \\
\hline CD19 & $41(3-1270)$ & $124(20-838)$ & $28(8-383)$ & $217(34-820)$ & 0.7 & 0.09 \\
\hline CD68 & $860(224-1969)$ & $657(228-1779)$ & $5858(279-1900)$ & $942(394-2273)$ & 0.8 & 0.2 \\
\hline
\end{tabular}

Data are presented as median number of cells $\cdot \mathrm{mm}^{-2}$ (range). p-values are given for comparisons between groups.

in the majority of the cells. Numbers of cells in the epithelium and lamina propria did not show significant differences between the groups (table 2).

T-cells. CD4-positive cells varied considerably between biopsy specimens. Normally, the majority of cells were situated in the subepithelial space in the lamina propria. Sometimes infiltrates were seen. No statistically significant differences were found between the groups. The medians and ranges of numbers of cells are shown in table 2.

CD8-positive cells were evenly distributed in the lamina propria. Infiltrates were not encountered frequently. No statistical differences were found between the groups.

CD14+ cells. CD14+ cells are considered to represent cells belonging to the granulocyte/monocyte lineage. These cells were found in large quantities in the epithelium and lamina propria where they frequently formed infiltrates. For the epithelium, no significant differences could be detected. The lamina propria of the allergic group, however showed a marked tendency towards a higher number of cells $(\mathrm{p}=0.02)$ (table 2$)$.

CD $19+$ cells. B-cells were mainly seen in the lamina propria where they sometimes formed small subepithelial infiltrates. No significant differences in cell number were seen between the groups (table 2).

CD68+ cells. Macrophages were seen both in the epithelium and the lamina propria. In the former, these cells usually were more voluminous and displayed more intense coloration than their counterparts in the lamina propria. No tendency towards a higher number of cells was observed in the lamina propria in the allergic group (table 2).
Mast cells. Chymase-positive cells were statistically significantly more abundant in the epithelium of biopsy specimens in the allergic group $(\mathrm{p}=0.006)$ (table 3 and fig. 1). The lamina propria did not show this difference. The majority of the positive cells were located in this compartment. In the lamina propria, the majority of mast cells had an elongated spindle-shaped appearance. The positive cells in the nonallergic groups tended to be located in a layer beneath the basement membrane and diffusely in the glandular area, whereas positive cells in the allergic children tended to be evenly distributed throughout the lamina propria.

Tryptase-positive cells also demonstrated a significantly higher number of cells in the epithelium of allergic children $(\mathrm{p}=0.007)$. In the lamina propria, tryptase-positive cells showed a trend towards being more numerous in the allergic group $(p=0.04)$. The distribution of tryptase-positive cells was similar to that seen for chymase-positive cells (table 3 and fig. 1).

IgE-positive cells. IgE-positive cells were found both in the epithelium and lamina propria. Not all sections contained positive cells. When present, however, they showed the same distribution as described for mast cells. This cell type showed a significantly higher number of cells in the epithelium and lamina propria of allergic children $(\mathrm{p}=0.001$ and $\mathrm{p}=0.0001$ respectively) (table 3 and fig. 1).

Eosinophils. BMK13+ cells in the epithelium demonstrated two different patterns of cell staining. Cells were usually large when situated against the basal membrane in contrast to BMK13+ cells located at the outer edge of the epithelium. This probably reflects changes in granule contents of MBP during migration through the epithelium. No significant differences in numbers of cells were found between the groups. Cells in the lamina propria

Table 3. - Number of positive cells of cell types found in the nasal mucosa showing significant differences between groups of allergic children and age-matched nonallergic control subjects

\begin{tabular}{|c|c|c|c|c|c|c|}
\hline \multirow{2}{*}{$\begin{array}{l}\text { Antibody } \\
\text { against }\end{array}$} & \multicolumn{2}{|c|}{ Controls } & \multicolumn{2}{|c|}{ Allergic children } & \multicolumn{2}{|c|}{ p-values } \\
\hline & Epithelium & $\begin{array}{l}\text { Lamina } \\
\text { propria }\end{array}$ & Epithelium & $\begin{array}{l}\text { Lamina } \\
\text { propria }\end{array}$ & Epithelium & $\begin{array}{l}\text { Lamina } \\
\text { propria }\end{array}$ \\
\hline Tryptase & $0(0-9)$ & $57(20-145)$ & $9(0-143)$ & $93(25-281)$ & 0.007 & 0.04 \\
\hline Chymase & $0(0-14)$ & $86(15-204)$ & $9(0-64)$ & $92(40-268)$ & 0.006 & 0.1 \\
\hline IgE & $0(0-398)$ & $0(0-199)$ & $233(0-850)$ & $114(1-332)$ & 0.001 & 0.0001 \\
\hline BMK13 & $5(0-40)$ & $3(0-72)$ & $32(0-321)$ & $41(12-516)$ & 0.03 & 0.004 \\
\hline
\end{tabular}

Data presented as median number of cells $\cdot \mathrm{mm}^{-2}$ (range). p-values given for comparisons between groups. IgE: immunoglobulin E. 


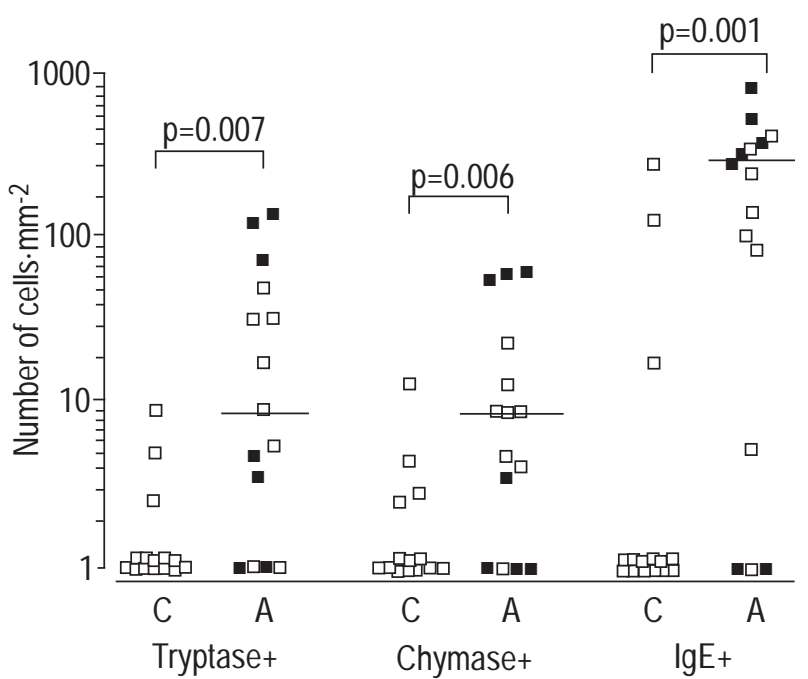

Fig. 1. - Logarithmic dot-plot of cell types showing significant differences between the epithelium of allergic $(\mathrm{A})$ children and nonallergic control (C) subjects. Median numbers of cells in the allergic group are depicted by horizontal bars (median numbers of cells in the control group are zero, not shown.) $\square$ : children without detectable specific immunoglobulin (Ig)E against aeroallergens; $\mathbf{\square}$ : allergic children with detectable specific serum IgE against aeroallergens. Note the distribution of numbers of cells in children with specific IgE against aeroallergens. For each cell type in this plot the highest numbers of cells belong to the same children. The same is true for the smallest cell numbers.

were mainly situated subepithelially. The rest of this compartment demonstrated an even distribution of positive cells. A statistically significant difference between the groups was found, with more BMK13+ cells in the allergic group $(\mathrm{p}=0.004)$ (table 3$)$.

\section{Double staining}

As described above, differences were found for IgEpositive cells in both compartments. To determine which IgE-carrying cell type contributed to this overall difference, double-staining tests were performed.

Langerhans' cells and IgE. Cells staining for CD1a were seen in the epithelium and the lamina propria, and their numbers correlated to the cell numbers seen in single staining. As in single staining, no statistically significant differences were found for CDla between the two groups (table 4). IgE-positive cells were again seen in both compartments and a statistically significant higher number of cells was seen in both the epithelium and the lamina propria (table 4). Double-staining cells were seen in the epithelium and lamina propria of four allergic children. These children also had large numbers of cells positive for IgE in single staining.

Tryptase- and chymase-positive cells and IgE. To determine total numbers of mast cells in each biopsy, a tryptase and chymase antibody mix was used in the first step of the double-staining procedure. The total number of positive cells in the lamina propria was approximately $15 \%$ higher than with single staining with either tryptase or chymase (data not shown). With the epithelium no such difference could be detected.

IgE-positive mast cells were sporadically seen in the mucosa of nonallergic control subjects. In the mucosa of allergic children a significantly increased number of IgEpositive mast cells was seen in both compartments (table 4). Approximately $28 \%$ of the mast cells in the allergic group presented IgE. In subjects with specific IgE against AA, $66 \%$ (range $21-85 \%$ ) of the mast cells presented IgE. In subjects without specific IgE against AA, only $11 \%$ (range $1-30 \%$ ) of the mast cells presented IgE. This difference was statistically significant $(\mathrm{p}=0.04)$.

Total serum IgE and cell types. A high total serum IgE was the inclusion criterion for all children in the allergic group. Correlations between total serum $\operatorname{IgE}$ and the number of positive cells found in each patient were examined. This was carried out for all IgE-related cell types (mast cells, eosinophils, B-cells and Langerhans' cells). One subject in the allergic group had to be excluded because of a missing total serum IgE value (patient No.13 in table 1). Correlations between numbers of cells and total serum IgE were determined separately for subjects in the allergic group and subjects in the control group.

In the nonallergic control group, none of the numbers of cells of the different cell types correlated with total serum IgE. Only IgE-positive cells demonstrated any (weak) correlation with total serum $\operatorname{IgE}$, which reached significance for the lamina propria $(r=0.59 ; \mathrm{p}=0.01)$. Likewise, in the allergic group no correlation was found between the number of cells positive for chymase, tryptase, CD1a, CD19 or BMK13 and the total serum IgE found in each patient. All correlation coefficients were $<0.3$ and $p$-values $>0.05$ (data not shown). However, the number of cells positive for $\mathrm{IgE}$ in each subject showed a very strong correlation with the total serum $\operatorname{IgE}$ of the same patient (fig. 2). This was found in both the epithelium $\left(\mathrm{r}_{\mathrm{s}}=0.89\right.$; $\mathrm{p}=0.0001)$ and the lamina propria $\left(\mathrm{r}_{\mathrm{s}}=0.82 ; \mathrm{p}=0.0001\right)$ of the allergic subjects. The number of IgE-positive mast cells, as determined by double staining, did not correlate with total serum IgE.

Table 4. - Number of positive cells in double-staining experiments for immunoglobulin (Ig)E and Langerhans' cells (CD1a/ $\mathrm{IgE}$ ) and $\mathrm{IgE}$-positive mast cells (tryptase and chymase/lgE) in the nasal mucosa of allergic children and age-matched nonallergic control subjects

\begin{tabular}{|c|c|c|c|c|c|c|}
\hline \multirow{2}{*}{$\begin{array}{l}\text { Antibody } \\
\text { against }\end{array}$} & \multicolumn{2}{|c|}{ Controls } & \multicolumn{2}{|c|}{ Allergic children } & \multicolumn{2}{|c|}{ p-values } \\
\hline & Epithelium & Lamina propria & Epithelium & Lamina propria & Epithelium & Lamina propria \\
\hline CD1a & $197(33-438)$ & $29(7-49)$ & $217(80-419)$ & $36(6-105)$ & 0.7 & 0.6 \\
\hline $\operatorname{IgE}$ & $0(0-20)$ & $7(0-56)$ & $11(0-417)$ & $31(4-314)$ & 0.01 & 0.02 \\
\hline CD1a/IgE & 0 & $0(0-1)$ & $0(0-122)$ & $2(0-39)$ & 0.02 & 0.003 \\
\hline Tryptase and chymase $/ \operatorname{IgE}$ & $0(0-1)$ & $2(0-29)$ & $3(0-19)$ & $42(5-131)$ & 0.005 & 0.0002 \\
\hline
\end{tabular}

Data are presented as median number of cells $\cdot \mathrm{mm}^{-2}$ (range). $\mathrm{p}$-values are given for comparisons between groups. 


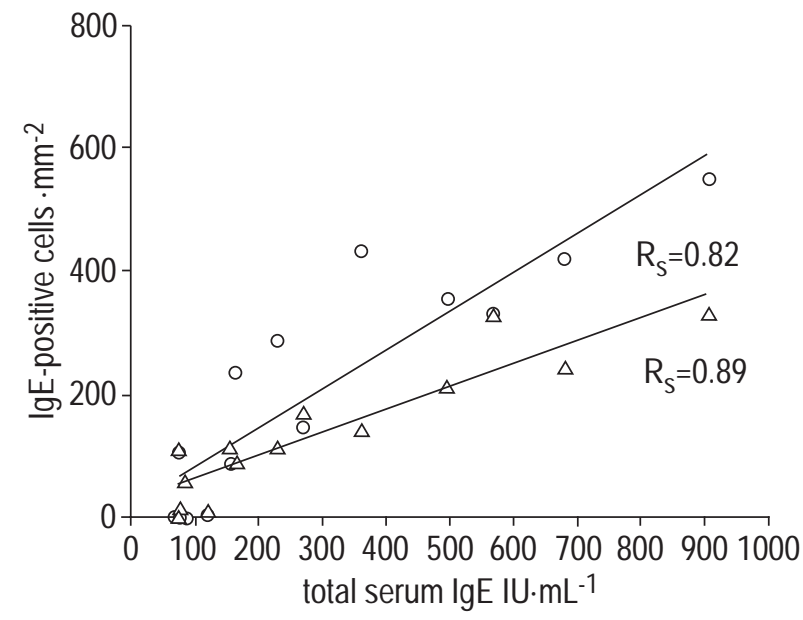

Fig. 2. - Scatter diagram of total serum immunoglobulin (Ig)E and the number of IgE-positive cells in the epithelium $(O)$ and lamina propria $(\triangle)$ for patients in the allergic group. Lines represent trends between total serum $\operatorname{IgE}$ and cellular $\operatorname{IgE}$.

\section{Discussion}

To the authors' knowledge no data has yet been produced on cellular infiltrates in the nasal mucosa during the developing stages of allergic rhinitis. Current knowledge on this subject is based on data collected in adults or obtained from children by nasal lavage and scrapings [412].

In early childhood it is not always easy to prove that a child is allergic, because of the absence of a clear-cut medical history and the lack of fully reliable laboratory tests. To include atopic children without specific serum IgE in the allergic group, the inclusion criteria mentioned earlier were used. These inclusion criteria were based on parameters that are thought to be indicative of allergic disease [15-17]. The allergic group was age-matched with the nonallergic control group. A match for sex could not be made. More males were included in the allergic group than the nonallergic control group. This is in accordance with the finding that allergic disease is more widespread in male than in female children [18].

Differences in mast cell number were found mainly in the epithelium. The distribution of mast cells found was similar to that seen in the nasal mucosa of allergic adults [4, 6]. The degree of migration to the epithelium depends on the allergen load [19]. Some of the allergic children with specific IgE against AA had low mast cell counts, while others had high counts (fig. 1). This difference can possibly be attributed to the degree of natural allergen provocation prior to the biopsy.

A median of $30 \%$ of the mast cells in the allergic group were found to be IgE-positive. The percentage of mast cells positive for IgE depended primarily on the presence of specific IgE against AA. The differences found were not due to higher overall levels of serum $\operatorname{IgE}$ in the allergic children with specific serum IgE against AA.

Eosinophils play a pivotal role in allergic diseases, such as asthma and rhinitis, as has been demonstrated by numerous studies [20-22]. Within an hour after allergen provocation, eosinophils can be detected in nasal smears $[22,23]$ and persistent eosinophilia is seen for up to 2 weeks after allergen provocation [22]. The presence of eosinophils and the absence of mast cells in some children in the allergic group may be explained by the idea that mast cell response to allergen provocation is comparatively "fast and furious", while eosinophil response is "slow but stable".

Langerhans' cells form a network of antigen-presenting cells in the respiratory mucosa [24] and play an important role in allergen presentation in allergic rhinitis [8, 25]. These antigen-presenting cells are seen in larger numbers in the nasal mucosa of allergic adults, and increase in number after allergen provocation. By analogy with the situation seen in adults, it was expected that there would be a larger number of Langerhans' cells in the nasal mucosa of allergic children. However, no differences were found. The mucosal lining of the upper airways of children reacts differently to external pathogens than that of adults, as can be concluded from the difference in prevalence of rhinitis. This difference can reflect the "immature" immune system of children. McWiLLiam et al. [26] demonstrated an influx of Langerhans' cells in the respiratory epithelium of rats following challenges with virus, bacteria and soluble proteins. By analogy with the situation found in rat respiratory epithelium, the constant exposure to antigenic particles could also lead to an influx of Langerhans' cells in the human mucosa. This influx was found in the nasal mucosa of the allergic group as well as the nonallergic control group. Because of this, the allergic component of the Langerhans' cells influx is overshadowed, which leads to an absence of differences in cell numbers.

IgE positivity on CD1a+ cells was only found in the nasal mucosa of patients with specific serum IgE against AA. Further experiments need to be carried out in order to find out whether or not these $\operatorname{IgE}$ molecules are specific for the allergens to which the subject has become sensitized, as has been demonstrated in adults by KLEINJAN et al. [27].

More cells were found to be positive for IgE in the nasal mucosa of allergic subjects than in nonallergic control subjects, as has been described in adult nasal mucosa [28]. As described in adults, these IgE-positive cells are mainly mast cells [6, 7] and Langerhans' cells $[8,25]$. The total number of IgE-positive cells in the epithelium and lamina propria of allergic children showed a strong correlation with total serum $\operatorname{IgE}\left(r_{s} \geq 0.82 ; p=0.0001\right)$. This could be explained by the hypothesis that when IgE receptor (Fce$\mathrm{RI} / \mathrm{RII}$ )-carrying cells are situated in an environment containing high levels of IgE this leads to an increased total IgE-positive cell count. This hypothesis is strengthened by the observation that serum IgE levels induce basophil and mast cell IgE receptor display [29]. However, the hypothesis does not appear to be valid in the present study because of the following two reasons: 1) the percentage of mast cells presenting IgE did not depend on the total serum $\operatorname{IgE}$ level but on the presence of specific serum $\operatorname{IgE}$ against AA; and 2) IgE-positive Langerhans' cells were only found in children with specific serum $\operatorname{IgE}$ against AA.

In conclusion, the nasal mucosa of allergic children differs from nonallergic children and the cell types involved show similarities with the situation described in adults. Cellular changes can be detected before specific serum immunoglobulin $\mathrm{E}$ is present. Although the number of immunoglobulin E-positive cells appears to correlate with total serum immunoglobulin $\mathrm{E}$, the number of immunoglobulin E-positive mast cells and Langerhans' cells is linked to the presence of aeroallergen-specific serum 
immunoglobulin E. These findings suggest that medical treatment of very young allergic children can be useful. Furthermore, the nasal biopsy technique is a safe method for future studies in children with allergic rhinitis.

\section{References}

1. Howarth PH, Holmberg K. Allergic rhinitis: an increasing clinical problem. Allergy 1995; 50 (Suppl. 23): 4-5.

2. Varonier HS. Prevalence of respiratory allergy among children and adolescents in Geneva, Switzerland. Respiration 1970; 27 (Suppl. 1): 115-120.

3. Aberg N. Asthma and allergic rhinitis in Swedish conscripts. Clin Exp Allergy 1989; 19: 59-63.

4. Bentley AM, Jacobson MR, Cumberworth V, et al. Immunohistology of the nasal mucosa in seasonal allergic rhinitis: increases in activated eosinophils and epithelial mast cells. J Allergy Clin Immunol 1992; 89: 877-883.

5. Fokkens WJ, Holm AF, Rijntjes E, Mulder PG, Vroom TM. Characterization and quantification of cellular infiltrates in nasal mucosa of patients with grass pollen allergy, non-allergic patients with nasal polyps and controls. Int Arch Allergy Appl Immunol 1990; 93: 66-72.

6. Fokkens WJ, Godthelp T, Holm AF, et al. Dynamics of mast cells in the nasal mucosa of patients with allergic rhinitis and non-allergic controls: a biopsy study. Clin Exp Allergy 1992; 22: 701-710.

7. Igarashi $\mathrm{Y}$, Goldrich MS, Kaliner MA, Irani AM, Schwartz LB, White MV. Quantitation of inflammatory cells in the nasal mucosa of patients with allergic rhinitis and normal subjects. J Allergy Clin Immunol 1995; 95: 716-725.

8. Godthelp T, Fokkens WJ, Kleinjan A, et al. Antigen presenting cells in the nasal mucosa of patients with allergic rhinitis during allergen provocation. Clin Exp Allergy 1996; 26: 677-688.

9. Miller RE, Paradise JL, Friday GA, Fireman P, Voith D. The nasal smear for eosinophils. Its value in children with seasonal allergic rhinitis. Am J Dis Child 1982; 136: 1009-1011.

10. Zeiger RS, Heller S. Development of nasal basophilic cells and nasal eosinophils from age 4 months through 4 years in children of atopic parents. J Allergy Clin Immunol 1993; 91: 723-734.

11. Meltzer EO. Nasal cytological changes following pharmacological intervention. Allergy 1995; 50 (Suppl. 23): $15-20$.

12. Nagayama Y, Odazima Y, Nakayama S, Toba T, Funabashi S. Eosinophils and basophilic cells in sputum and nasal smears taken from infants and young children during acute asthma. Pediatr Allergy Immunol 1995; 6: 204208.

13. Lim MC, Taylor RM, Naclerio RM. The histology of allergic rhinitis and its comparison to cellular changes in nasal lavage. Am J Respir Crit Care Med 1995; 151: 136144.

14. Fokkens WJ, Vroom TM, Gerritsma V, Rijntjes E. A biopsy method to obtain high quality specimens of nasal mucosa. Rhinology 1988; 26: 293-295.
15. Abdulrazzaq YM, Bener A, DeBuse P. Association of allergic symptoms in children with those in their parents. Allergy 1994; 49: 737-743.

16. Zeiger RS, Heller S. The development and prediction of atopy in high-risk children: follow-up at age seven years in a prospective randomized study of combined maternal and infant food allergen avoidance. J Allergy Clin Immunol 1995; 95: 1179-1190.

17. Lilja G, Oman H, Johansson SG. Development of atopic disease during childhood and its prediction by Phadiatop Paediatric. Clin Exp Allergy 1996; 26: 1073-1079.

18. Arshad SH, Stevens M, Hide DW. The effect of genetic and environmental factors on the prevalence of allergic disorders at the age of two years. Clin Exp Allergy 1993; 23: 504-511.

19. Peebles RS Jr, Togias A. Role of mast cells and basophils in rhinitis. Chem Immunol 1995; 62: 60-83.

20. Moqbel R, Barkans J, Bradley BL, Durham SR, Kay AB. Application of monoclonal antibodies against major basic protein (BMK-13) and eosinophil cationic protein (EG1 and EG2) for quantifying eosinophils in bronchial biopsies from atopic asthma. Clin Exp Allergy 1992; 22: 265273.

21. Terada N, Konno A, Togawa K. Biochemical properties of eosinophils and their preferential accumulation mechanism in nasal allergy. J Allergy Clin Immunol 1994; 94 : 629-642.

22. Godthelp T, Holm AF, Fokkens WJ, et al. Dynamics of nasal eosinophils in response to a nonnatural allergen challenge in patients with allergic rhinitis and control subjects: a biopsy and brush study. J Allergy Clin Immunol 1996; 97: 800-811.

23. Bascom R, Pipkorn U, Lichtenstein LM, Naelerio RM. The influx of inflammatory cells into nasal washings during the late response to antigen challenge. Effect of systemic steroid pretreatment. Am Rev Respir Dis 1988; 138: 406-412.

24. Holt PG, Oliver J, McMenamin C, Schon-Hegrad MA. Studies on the surface phenotype and functions of dendritic cells in parenchymal lung tissue of the rat. Immunology 1992; 75: 582-587.

25. Fokkens WJ, Bruijnzeel-Koomen CA, Vroom TM, et al. The Langerhans cell: an underestimated cell in atopic disease. Clin Exp Allergy 1990; 20: 627-638.

26. McWilliam AS, Napoli S, Marsh AM, et al. Dendritic cells are recruited into the airway epithelium during the inflammatory response to a broad spectrum of stimuli. $J$ Exp Med 1996; 184: 2429-2432.

27. KleinJan A, Godthelp T, van Toornenenbergen AW, Fokkens WJ. Allergen binding to specific IgE in the nasal mucosa of allergic patients. J Allergy Clin Immunol 1997; 99: 515-521.

28. Bachert C, Prohaska P, Pipkorn U. IgE-positive mast cells on the human nasal mucosal surface in response to allergen exposure. Rhinology 1990; 28: 149-158.

29. MacGlashan DW Jr, Bochner BS, Adelman DC, Jardieu PM, Togias A, Lichtenstein LM. Serum IgE level drives basophil and mast cell IgE receptor display. Int Arch Allergy Immunol 1997; 113: 45-47. 